\author{
M. Olkhova, D. Roslavtsev, A. Mykhalenko
}

O.M. Beketov National University of Urban Economy in Kharkiv, Ukraine

\title{
EFFECTIVENESS OF DELIVERY TRANSPORTATION PROCESS WHILE USING ELECTRIC FREIGHT VEHICLE
}

\begin{abstract}
The paper is devoted to determining the efficiency of the transport process for the delivery of confectionery products within the city. Comparing electric and diesel type of freight vehicles it was made conclusions about the advantages of choosing a mode of freight transport in Kharkiv.
\end{abstract}

Keywords: city logistics, electric freight vehicle, route, transportation.

\section{Formulation of the problem}

Urban freight transport (UFT) is important for transporting goods, especially confectionery that is in demand and needs special attention during transportation, but many negative sustainability impacts can influence on the process. The environmental impact of urban freight transport increases with population density and urban stagnation. According to experts from the leading German logistics company Deutsche Post DHL Group, there is a need for more efficient freight transport systems that not only take into account costs but also completely solve environmental problems [1]. In studies of European Commission in the field of logistics, urban freight traffic is more polluting than long distance transportation, due to the average lifetime of vehicles and the large numbers of short trips and stops. Freight traffic is about one quarter of $\mathrm{CO}_{2}$ emissions from transport operations in cities [2]. One of the solutions to reduce negative impact, that becomes more popular nowadays, is electric freight vehicle (EFV). Unfortunately, there are not a lot of papers devoted to the evaluation of effectiveness of freight transportation by EFV in Ukraine despite the fact that there are huge environmental challenges existing in this country.

\section{Analysis of recent research and publications}

Implementation of EFVs in city logistics is connected with some advantages - lack of gaseous or solid pollutant emissions [3], lack of noise emissions, energy efficiency [4]. Paper [5] describes assessing the potential of EFV to reduce freight transport GHG emissions in France taking into account vehicle range and urban congestion. The results show that electrification of freight vehicles should be done in cities bigger than 100000 inhabitants, because of high concentration $\mathrm{CO}_{2}$. Using any type of fully electrically powered vehicle implies a significantly lower consumption cost and price of $\mathrm{kWh}$ comparing to any gasoline or diesel car [6-8]. Considering that more than $80 \%$ of the deliveries are of distances about $80-100 \mathrm{~km}$ in European urban areas, the use of EFV for city logistics operations could be a feasible option in operational terms $[9,10]$.

Two types of measures can be executed the electrification of urban freight traffic: regulation - a limitation of access to diesel (or to most pollutant) vehicles in specific zones (Low Emission Zone), a priority given to electric vehicles or an obligation to deliver by this type of vehicle [4]. The research [11] also shows differences between electric truck and diesel truck in delivery comparing the most relevant issues energy use, emissions and energy cost. The consumption of the vehicle depends on the capacity of its battery and the type of driving, so it could be estimated that costs on electricity about $40 \%$ lower than that of internal combustion engines for the same distance. In article [12] considered positive and negative technological features «The FREVUE project», like an acute turning range, steering circle and improved visibility facilitate the maneuvering of the vehicles in dense city areas, charging, load capacity, maintenance and the need to adapt logistic concepts for the usage of EFVs.

\section{The aim of the paper}

The aim of the paper is to determine areas of effectiveness of transportation process of delivery confectionery products while using electric freight vehicle in the city.

\section{Research system description}

Most of the shipments in Ukraine are carried by vehicles with internal combustion engines and there are practically no examples of using EFVs. As an object, we chose transportation of confectionery products because it occupies a sufficiently large part of traffic in the city. There are wide ranges of different 
confectionary manufacturers in Ukraine on the one hand, and there is a huge demand for such products from consumers, on the other hand. For this reason, movement of confectionary good is motivating to research.

Particular attention during the organization of transportation requires confectionery. It is important to adhere to sanitary requirements and temperature regime. The group of these goods is perishable, so transportation should take minimal time. Permissible time of confectionery staying on the road depends on the timing of the sale of the products. An automobile carrying cargo transportation of confectionery products must be necessarily certified. Transportation is carried out in trucks with refrigerators, specialized vans, allowing to store the required temperature and humidity for a long time. Packing of products should keep their appearance. Products are packed in cardboard and plastic boxes, and fragile products are transported in corrugated boxes. However, it is unacceptable to assemble products at each other. For transportation in vans, special shelves should be provided. According to this special equipment for transportation, vehicles have such a high price.

At the first stage, we divided all confectionery manufacturers existing in Kharkiv into production sizes, including small, medium and large ones, Fig. 1. One of the largest manufacturers of confectionery products, which are sold within the city of Kharkiv, is the Kharkiv Biscuit Factory (Lozovsky str. 8).

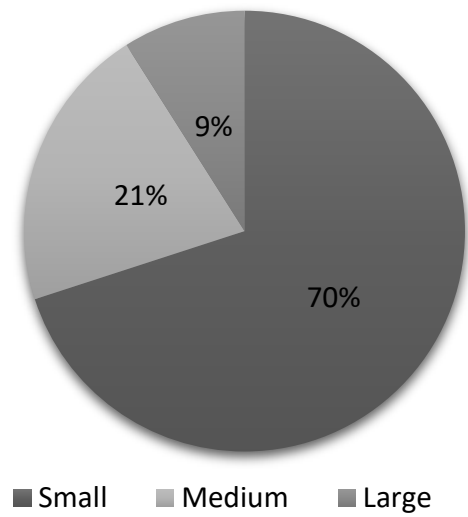

Fig. 1. Numbers of confectionery manufacturers in percentage

Consumers of finished products can also be distributed according to the size of consumption, namely: small retail chains, middle-store supermarkets and large retail chains. In this work, we chose middle supermarket chain "ATB". It is one of the biggest retail chains in Ukraine that is dynamically developing. This enterprise has about 56 supermarkets in Kharkiv, Fig. 2.

At the second stage, we chose two types of vehicles: electric driven and diesel driven to compare the effectiveness of its using. Capacity of the both vehicles are the same $-4,5 \mathrm{t}$., but each vehicle has its advantages and disadvantages.

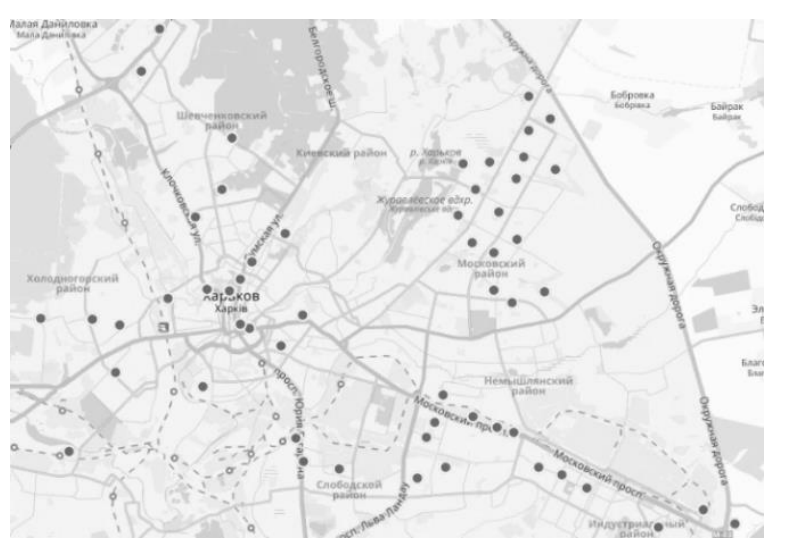

Fig. 2. Location of the "ATB" supermarkets in Kharkiv

For example, electric vehicle is eco-friendly because it runs on electrically powered engines. It is not produced emissions or other pollutants. However, EFV has limits by range $(100 \mathrm{~km})$ and recharging time. Diesel driven vehicle is more affordable, especially on the Ukrainian market. The general characteristics of vehicles is presented in Tab.1.

Table 1

Characteristics of vehicles

\begin{tabular}{|c|c|c|}
\hline Parametrs & $\begin{array}{c}\text { Fuso } \\
\text { eCanter }\end{array}$ & $\begin{array}{c}\text { Foton } \\
1069\end{array}$ \\
\hline Fuel type & electric & diesel \\
\hline Capacity, ton & 4,5 & 4,5 \\
\hline $\begin{array}{c}\text { Energy/fuel } \\
\text { consumption/100km }\end{array}$ & $82 \mathrm{kWh}$ & $15 \mathrm{~L}$ \\
\hline Motor power, kW & 115 & 101 \\
\hline Maximum speed, km/h & 80 & 95 \\
\hline Price, thousand UAH & 928 & 600 \\
\hline
\end{tabular}

\section{Modelling of delivery transportation process of confectionary products}

The criterion of the effectiveness of transportation process is the total operating costs:

$$
C \rightarrow \min \text {. }
$$

The mathematical model of the logistics chain has been developed. The mathematical model of an optimization:

$$
C=\min \left\{\mathrm{C}_{\mathrm{E}} ; \mathrm{C}_{D}\right\},
$$

where $\mathrm{C}_{\mathrm{E}}-$ total operating costs while transporting cargo by electric vehicle, UAH per year; $\mathrm{C}_{D}-$ total operating costs while transporting cargo by diesel driven vehicle, UAH per year.

Total operating costs while transporting cargo by electric or diesel vehicle are calculated by the following formula:

$$
C=C_{s}+C_{r}+C_{f}+C_{t}+C_{g},
$$

where $C_{s}-$ costs of salaries, UAH per year; $C_{r}-$ maintenance costs of vehicle, UAH per year; $C_{f}$ - fuel costs of vehicle, UAH per year; $C_{t}-$ tire 
costs, UAH per year; $C_{g}-$ general expenses of operating activity, UAH per year

In order to conduct a comparative analysis of the efficiency of the using selected vehicles, it is necessary to form a technology for the operation of freight transport. During the development of the process of delivery confectionery products, the service "Ant Logistics" was used [13]. This platform allows building

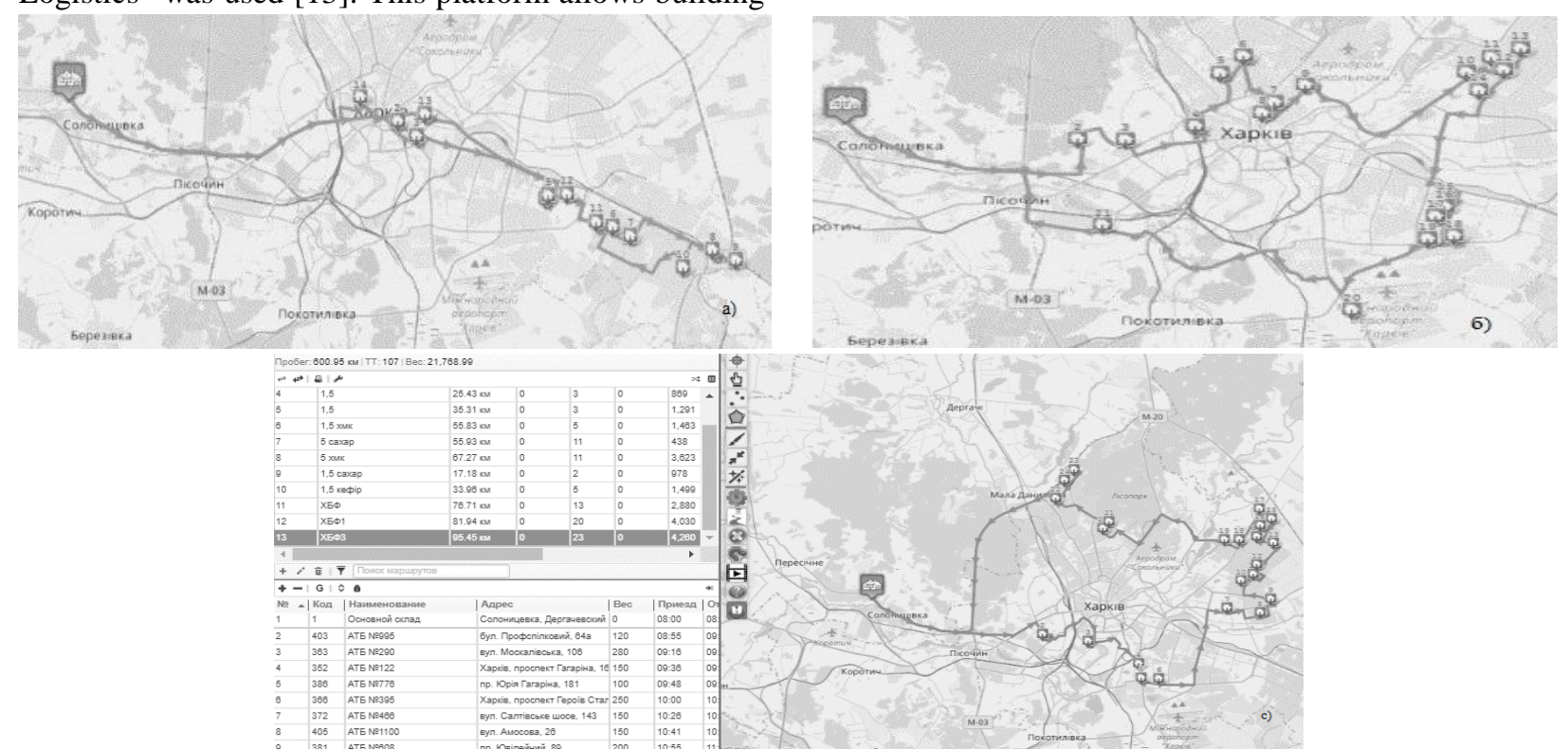

Fig. 3. Scheme of routes: a) route №1; b) route №2; c) route №3

Characteristics of routes

\begin{tabular}{|c|c|c|c|c|}
\hline Number of routes & Distance, $\mathrm{km}$ & Delivery time, $\mathrm{h}$ & Number of stops & Weight, $\mathrm{kg}$ \\
\hline 1 & 76,71 & 5,35 & 13 & 2880 \\
\hline 2 & 81,94 & 6,88 & 20 & 4030 \\
\hline 3 & 95,45 & 7,78 & 23 & 4260 \\
\hline
\end{tabular}

As the main limitation in our chosen electric vehicle is the mileage without recharging $-100 \mathrm{~km}$, then our formed routes are suitable for both vehicles. Having analyzed the technology for the existing conditions, there are no differences. According to this

delivery routes, taking into account the following factors: type of car, load capacity, type of goods and their weight, journey time of delivery. Result of work in program is formation of three routes. The routes are shown in Fig. 3.

The main characteristics of developed routes are presented in Tab. 2.

Table 2

information, we made a schedule of arrival in each store. Detailed information about points of delivery on first route is presented in Tab. 3 .

Fig. 4 shows a schedule of the vehicle arrival to each supermarket.

Table 3

Schedule on route №1

\begin{tabular}{|c|c|l|c|c|c|c|}
\hline № & Name of store & \multicolumn{1}{|c|}{ Address } & Weight, kg & Distance, $\mathrm{km}$ & Arrival, $\mathrm{h}$ & Departure, $\mathrm{h}$ \\
\hline 1 & Warehouse & Solonitsevka & 0 & 0,00 & $8: 00$ & $8: 30$ \\
\hline 2 & ATB №406 & Vernadsky str., 12 & 400 & 15,69 & $9: 01$ & $9: 16$ \\
\hline 3 & ATB №1056 & Gagarina ave., 39 b & 100 & 1,71 & $9: 19$ & $9: 29$ \\
\hline 4 & ATB №410 & Tankopia str., 23 & 150 & 8,14 & $9: 45$ & $9: 55$ \\
\hline 5 & ATB №716 & Kharkiv divisions str., 12 a & 200 & 0,28 & $9: 56$ & $10: 06$ \\
\hline 6 & ATB №383 & Aleksandrovsky ave., 85 & 200 & 4,04 & $10: 14$ & $10: 24$ \\
\hline 7 & ATB №738 & Aleksandrovsky ave., 103/41 & 150 & 1,05 & $10: 26$ & $10: 36$ \\
\hline 8 & ATB №568 & Moskovsky ave., 300 & 310 & 5,20 & $10: 46$ & $10: 56$ \\
\hline 9 & ATB №249 & Velyka Kiltseva str., 3 & 200 & 1,48 & $10: 59$ & $11: 09$ \\
\hline 10 & ATB №1037 & Roganska str., 100th & 220 & 4,08 & $11: 17$ & $11: 27$ \\
\hline 11 & ATB №1007 & Aleksandrovsky ave., 114 & 280 & 6,09 & $11: 39$ & $11: 54$ \\
\hline 12 & ATB №592 & Rybalko str., 26 & 250 & 3,24 & $12: 00$ & $12: 10$ \\
\hline 13 & ATB №842 & Zakhysnykiv Ukrainy sq., 7/8 & 220 & 7,99 & $12: 26$ & $12: 36$ \\
\hline 14 & ATB №457 & Rizdviana str., 29 A & 200 & 3,48 & $12: 43$ & $12: 53$ \\
\hline 15 & Warehouse & Solonitsevka & 0 & 14,24 & $13: 21$ & - \\
\hline
\end{tabular}




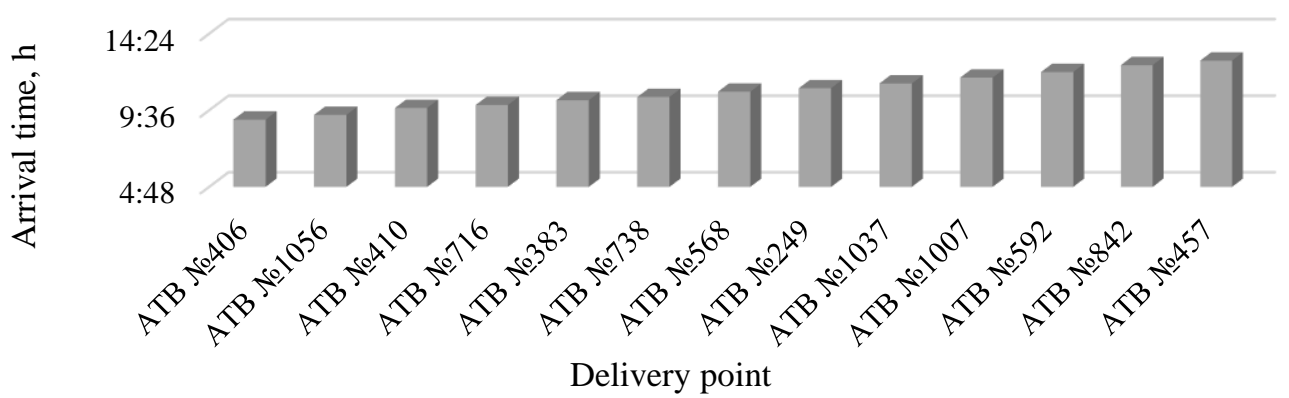

Fig. 4. Schedule of delivery goods on route №1

Analysis and assessment of transport activity is impossible without a set of indicators by which the volume and quality of its work is measured. Another important indicator is time, because transportation of confectionary products should occur in the shortest possible time. Delivery time consists of different stages, not all of them depends on transport operator. For instance, technological process of delivery can be split into different stages, Fig. 5. In this research we took into consideration time that vehicle spent for loading in the manufacture to time for unloading and time spent to return to manufacture (from last point).

Based on the received data from service Ant Logistics, the most important indicators, which allows to asses transportation process, were calculated, Tab. 4.

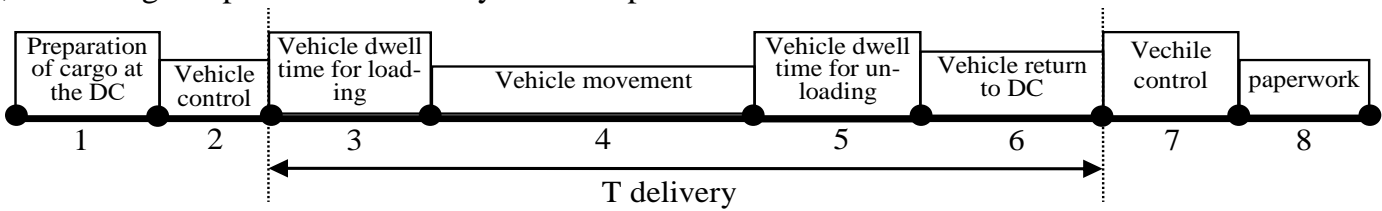

Fig. 5. Scheme of the transportation process delivery of confectionery in the city [14]

Table 4

Results of calculations of transport operation indicators on routes

\begin{tabular}{|c|c|c|c|c|c|c|c|c|c|}
\hline $\begin{array}{c}\text { № of } \\
\text { route }\end{array}$ & $\begin{array}{c}\text { Distance, } \\
\mathrm{km}\end{array}$ & $\begin{array}{c}\text { Mileage } \\
\text { loading, } \mathrm{km}\end{array}$ & $\begin{array}{c}\text { Mileage } \\
\text { from last } \\
\text { point (no } \\
\text { cargo), } \mathrm{km}\end{array}$ & $\begin{array}{c}\text { Time form } \\
\text { depot to } \\
\text { manufacture, } \mathrm{h}\end{array}$ & $\begin{array}{l}\text { Mileage use } \\
\text { coefficient }\end{array}$ & $\begin{array}{c}\text { Loading } \\
\text { coefficient }\end{array}$ & $\begin{array}{c}\text { Travel } \\
\text { time, } \mathrm{h}\end{array}$ & $\begin{array}{c}\text { Loading/ } \\
\text { unloading } \\
\text { time, } \mathrm{h}\end{array}$ & $\begin{array}{c}\text { Delivery } \\
\text { time, } \mathrm{h}\end{array}$ \\
\hline 1 & 76,71 & 62,47 & 14,24 & 0,47 & 0,81 & 0,64 & 2,52 & 2,83 & 5,35 \\
\hline 2 & 81,94 & 70,27 & 11,68 & 0,38 & 0,86 & 0,9 & 2,72 & 4,17 & 6,88 \\
\hline 3 & 95,45 & 76,67 & 18,77 & 0,63 & 0,8 & 0,95 & 3,2 & 4,58 & 7,78 \\
\hline
\end{tabular}

Having obtained full information about the formed routes, we can proceed to financial analysis of the effectiveness of transportation process using different vehicles, as this is the main indicator (3). The results are shown in Tab. 5. The difference between using diesel and electric vehicles is equal to 403679 UAH per year or to $41 \%$. This is a quite significant value for transport operators, taking into account delivery only confectionary goods from one manufacture.

Characteristics of operating costs on routes per year

\begin{tabular}{|c|c|c|c|c|c|c|c|}
\hline $\begin{array}{c}\text { Vehicle } \\
\text { type }\end{array}$ & $\begin{array}{c}\text { Costs of } \\
\text { salaries, } \\
\text { UAH }\end{array}$ & $\begin{array}{c}\text { Maintenance } \\
\text { costs of vehicle, } \\
\text { UAH }\end{array}$ & $\begin{array}{c}\text { Fuel costs } \\
\text { of vehicle, } \\
\text { UAH }\end{array}$ & $\begin{array}{c}\text { Charge cost, } \\
\text { (kWh per km), } \\
\text { UAH }\end{array}$ & $\begin{array}{c}\text { Tire costs, } \\
\text { UAH }\end{array}$ & $\begin{array}{c}\text { General } \\
\text { expenses of } \\
\text { operating } \\
\text { activity, UAH }\end{array}$ & $\begin{array}{c}\text { Total } \\
\text { operating } \\
\text { costs, UAH } \\
\text { per year }\end{array}$ \\
\hline Diesel & 544500 & 60702,49 & 204554,2 & - & 12333,42 & 156197,1 & 978287,2 \\
\hline Electric & 544500 & 501,35 & - & 8781,67 & 12333,42 & 8491,74 & 574608,1 \\
\hline
\end{tabular}

\section{Environmental assessment}

The developed transport network plays a huge role in the development of the state, but this is accompanied by pronounced consequences of the negative impact of transport on the environment [16]. Among all types of transport, automobiles cause the greatest damage to the environment, polluting the air with toxic components. The highest level of air pollution is observed in urban area where people suffering the most $[17,18,19]$.

From the point of view of the conducted financial analysis, there was a significant economy in finance by 
$41 \%$ if using the electric truck. There is also indirect impact that can be assessed in improving the environmental indicators during use vehicles [20].

Environmental assessment we provide with software COPERT. This is a program, which was developed in Europe and used worldwide to calculate air pollution and greenhouse gas emissions from the road transport sector. Since we consider only the operation of vehicles, then our chosen electric vehicle is emission free, but with diesel vehicle, the situation is much more complicated. A diesel engine is a selfigniting engine in which fuel and air are mixed inside the engine. Numbers of harmful products are generated during combustion. The most significant harmful products are carbon monoxide, hydrocarbons, particulate matter and nitrogen oxides. In addition, it should be taken into account that the transport is one of the largest sector in producing global $\mathrm{CO}_{2}$ emissions that leads to climate change [15]. Results of calculating emissions while transporting confectionery to "ATB" chain using methodology of COPERT is presented in Tab. 6.

Diesel engine emissions per year (Foton 1069)

\begin{tabular}{|c|c|c|c|c|}
\hline $\begin{array}{c}\text { Emission } \\
\mathrm{s}, \mathrm{kg}\end{array}$ & $\begin{array}{c}\text { Urban } \\
\text { Off } \\
\text { Peak }\end{array}$ & $\begin{array}{c}\text { Urban } \\
\text { Peak }\end{array}$ & Highway & Total \\
\hline $\mathrm{CO}_{2}$ & 221,39 & 3527,9 & 516,86 & 4266,13 \\
\hline $\mathrm{CO}$ & 0,2 & 5,3 & 0,5 & 6 \\
\hline $\mathrm{NO}_{\mathrm{x}}$ & 1,2 & 20 & 2,8 & 24 \\
\hline $\mathrm{PM}$ & 0,1 & 1,6 & 0,3 & 1,9 \\
\hline
\end{tabular}

\section{Conclusion}

The purpose of the paper was to determine the practicability of using the electric vehicle in city logistics, especially for transporting confectionary products in Kharkiv. We reviewed the process of delivery of the confectionery products of the Kharkiv Biscuit Factory through the network of supermarkets "ATB". Using a software product, we created routes and calculated the main indicators that allows estimating completed work on developed routes. In our paper, we consider technological process of delivery, in particular, time that vehicle spent for loading in the manufacture to time for returning to manufacture.

The main criterion for the effectiveness of transport on the routes was minimization of total operating cost. After conducting research, we concluded that the use of electric transport within the city for transportation at a given mileage can reduce total costs at least by $41 \%$. Also taking into account the indirect impact, we considered the effect from freight transport on the environment. Having analyzed the principle of operation of a diesel engine and what harmful substances it can produce, using the software product COPERT we calculated the main emissions from diesel vehicle $\left(\mathrm{CO}_{2}, \mathrm{CO}, \mathrm{NO}, \mathrm{PM}\right)$ for the year.

Of course, comparing these two vehicles without a doubt under the given conditions, it is necessary to give preference to electric transport, which is gradually becoming popular not only in Europe, but also in Ukraine. Using of an electric vehicle, despite the fact that the cost of its buying is in several times higher than vehicles with internal combustion engines, in the process of operation, the electric shows quite good results. But in the further research it is appropriate to include in the model capital cost of vehicle and to apply economic analysis for evaluation results.

\section{References}

1. Elichi Taniguchi. The Future of City Logistics, Germany. (2012) Retrieved from: https://delivering-tomorrow.com/thefuture-of-city-logistics

2. Ecorys, Fraunhofer, TCI, Prognos and AUEBRC/TRANSLOG. (2015). Fact-finding studies in support of the development of an EU strategy for freight transport logistics Lot 1: Analysis of the EU logistics sector, 119-125.

3. Iwan, S., Kijewska, K, Kijewski, D. (2014). Possibilities of Applying Electrically Powered Vehicles in Urban Freight Transport.

4. Quak, H., Nesterova, N. (2014). Challenges and issues for implementation of electric freight vehicles in city logistics, in C. Macharis et al.(eds.), Sustainable Logistics, 6 Transport and Sustainability series by Emerald Books, 265-294.

5. Rizeta, C., Cruzb, C., Vromant, M. (2015). The Constraints of Vehicle Range and Congestion for the Use of Electric Vehicles for Urban Freight in France.

6. Lin, J., Zhou, W., Wolfson, O. (2015). Electric vehicle routing problem.

7. Quak, H., Nesterova, N., Rooijen, T. (2015). Possibilities and barriers for using electric-powered vehicles in city logistics practice.

8. Timothy, E., Barder. (2016). Zero emission city logistics: current practices in freight electro mobility and feasibility in the near future.

9. Faulin, J., Armas, J., Grasma, S. (n.d.) Sustainable transportation based on electric vehicle concepts: a brief overview. DOI: $10.1039 / \mathrm{c} 001674$

10. Foltyński, M. (2014). Electric fleets in urban logistics Procedia - Social and Behavioral Sciences 151, 48 - 59.

11. Lee, D.Y., Thomas, V.M., Brown, M.A. (2013). Electric Urban Delivery Trucks: Energy Use, Greenhouse Gas Emissions and Cost-Effectiveness, Environmental Science and Technology 47, 8022-8030, 3-15.

12. FREVUE, 2013. State of the art of the electric freight vehicles implementation in city logistics, Frevue Deliverable $1.3,74$

13. Service. Retrieved from https://ant-logistics.com

14. Olkhova, M. V. (2009) Investigation of the time of service of the logistic system by a transport company. Municipal economy of cities, 90, 431-435.

15. Health Assessment Document for Diesel Engine Exhaust. (2002) National Center for Environmental Assessment, Office of Research and Development, US EPA. Washington D.C. EPA/600/8-90/057F, 9-11. 
16. European Commission. (2001). A sustainable Europe for a better world: A European Union strategy for sustainable development, Bruxelles.

17. Bauner, D., Laestadius, S., Iida, N. (2009). Evolving technological systems for diesel engine emission control: balancing GHG and local emissions. Clean Technol Environ Policy 11: 339-365.

18. Nuzzolo, A., Coppola, P. Comi, A. (2013). Freight transport modeling: review and future challenges. International Journal of Transport Economics, XL (2), 151181.

19. Nuzzolo, A., Crisalli, U., Comi, A. (2006). A modelling system for urban freight movements. In: Proceedings of 11th International Conference of Hong Kong Society for Transportation Studies - Sustainable Transportation, Hong Kong, China

20. Russo, F. and Comi, A. (2011). "Measures for sustainable freight transportation at urban scale: expected goals and tested results in Europe". In: Journal of Urban Planning and Development 137 (2), DOI: 10.1061/(ASCE)UP.19435444.0000052, American Society of Civil Engineers (ASCE), $142-152$.

\section{ЕФЕКТИВНІСТЬ ПРОЦЕСУ ДОСТАВКИ ПІД ЧАС ВИКОРИСТАННЯ ЕЛЕКТРИЧНОГО ВАНТАЖНОГО ТРАНСПОРТУ}

М.В. Ольхова, Д.М. Рославцев, А.Г. Михаленко

Харківський національний університет міського господарства імені О.М. Бекетова, Україна

Вплив міського вантажного транспорту на навколишнє середовище зростає із щільністю населення та бездіяльністю місиевої влади стосовно регулювання вантажного транспорту у місті. У дослідженнях Європейської Комісії у сфері логістики міський вантажний рух є більш забруднюючим, ніж перевезення на великі відстані, через середній термін експлуатації транспортних засобів та велику кількість коротких поїздок та зупинок. Вантажні перевезення - це приблизно чверть викидів $\mathrm{CO}_{2}$ від транспортних операцій у містах. Одним із рішень для зменшення негативного впливу, щяо набуває популярності сьогодні, $\epsilon$ використання вантажного електричного транспорту. На жаль, не так багато можна зустріти наукових робіт, присвячених оцінці ефективності вантажоперевезень по Україні, незважаючи на те, щзо в краӥні існують величезні екологічні проблеми. В даний час електромобілі $\epsilon$ хорошою альтернативою для підвищення стійкості в міській логістиці.

Міський вантажний транспорт має важливе значення для транспортування вантажів, особливо кондитерських виробів, які користуються попитом і потребують особливої уваги під час перевезень. Ця стаття присвячена визначенню ефективності транспортного прочесу під час доставки кондитерських виробів з використанням електричного вантажного автомобіля в межах міста. У якості критерію ефективності обрано експлуатаційні транспортні витрати.

Запропоновано два сценарії - використання електричного та дизельного типу вантажного транспорту з урахуванням основних особливостей транспортування кондитерських виробів. Було визначено технологію транспортного процесу доставки товарів. Оцінено основні показники роботи транспортних засобів на маршрутах, щзо були сформовані за допомогою он-лайн сервісу Ant Logistics. Taк, не було виявлено значних відмінностей між двома видами транспорту за технологією перевезення. Однак для проведення повного аналізу були визначені основні статті витрат. Існує тенденція до мінімізачії експлуатаційних витрат під час користування електричним видом транспорту.

Оскільки вплив вантажних перевезень на навколишнє середовище є одним із важливих факторів, було оцінено кількість викидів від дизельного двигуна за допомогою програмного продукту СОРЕRT та зроблено висновки щзодо переваг вибору виду транспорту для транспортування кондитерських виробів у Харкові.

Звичайно, порівнюючи изі два транспортні засоби в даних умовах, без сумніву слід віддати перевагу електричному транспорту, який поступово стає популярним не лише в Свропі, а й в Україні. Використання електромобіля, незважаючи на те, щзо вартість його закупівлі в кілька разів вище, ніж транспортних засобів з двигунами внутрішнього згоряння, демонструє досить непогані результати. Але в подальших дослідженнях доцільно включити в модель капітальну вартість транспортних засобів $i$ застосувати економічний аналіз для результатів оияінки.

Ключові слова: міська логістика, електричний вантажний транспорт, маршрут, перевезення. 